\title{
Endoscopic transcribriform resection of an olfactory groove meningioma and technical nuances
}

\author{
Peter Papagiannopoulos, ${ }^{1}$ Gregory Glauser, ${ }^{2}$ Nithin D Adappa, ${ }^{1}$ Omar Choudhri ${ }^{2}$
}

${ }^{1}$ Otorhinolaryngology, Perelman School of Medicine, University of Pennsylvania, Philadelphia, Pennsylvania, USA

${ }^{2}$ Neurosurgery, Hospital of the University of Pennsylvania,

Philadelphia, USA

\section{Correspondence to}

Gregory Glauser,

Gregory.glauser@uphs.upenn. edu

Accepted 30 May 2019
D) Check for updates

(c) BMJ Publishing Group Limited 2019. No commercial re-use. See rights and permissions. Published by BMJ.

To cite: Papagiannopoulos $P$ Glauser G, Adappa ND, et al. BMJ Case Rep 2019;12:e230316. doi:10.1136/bcr-2019230316

\section{DESCRIPTION}

This video illustrates a transcribriform resection of a symptomatic olfactory meningioma (figure 1). The patient described in this video is a 70-year-old man who presented with headaches and dysosmia. He was found to have an expanding olfactory meningioma on radiographic studies. Multiple treatment options were considered, including surveillance imaging, craniotomy for resection of the lesion and endoscopic transcribriform resection. For this case, endoscopic resection was the ideal treatment option as this approach avoids the need for brain retraction, with a higher chance for a Simpson Grade I Resection. The patient underwent endoscopic resection of the lesion with stereotactic navigation and extended skull base exposure with a Draf exposure and a lumbar drain in place. A few important technical nuances are addressed within this video. Of note, the bimanual microsurgical technique is useful for defining tumour margins, which is of the utmost importance in skull base procedures.

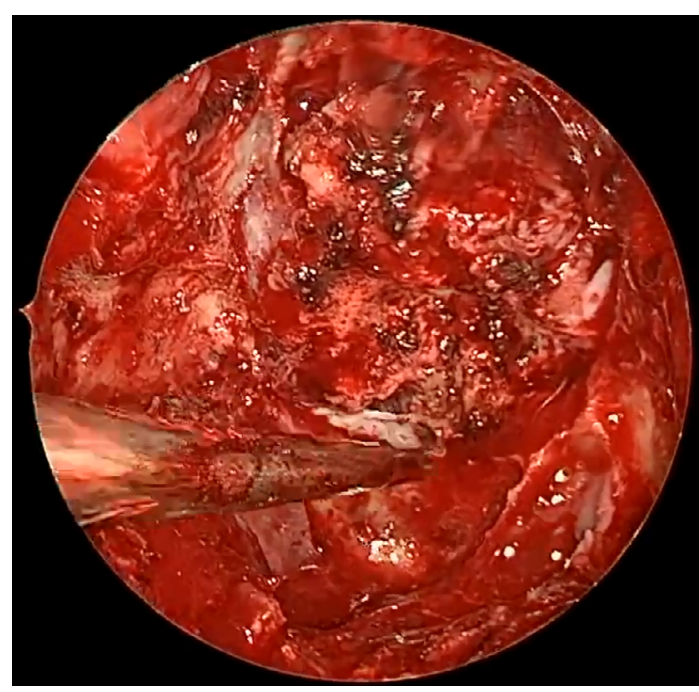

Figure 1 Operative view of olfactory groove meningioma.

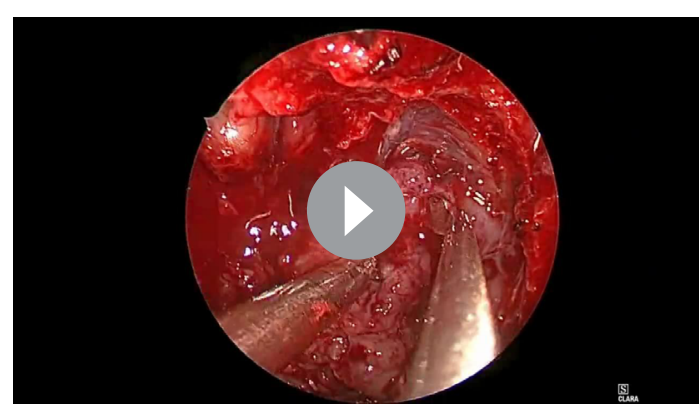

Video 1 Olfactory groove meningioma, endoscopic resection, transcribriform, skull base.

Learning points

- Endoscopic meningioma resection.

- Extended skull base exposure.

- Uncomplicated postoperative recovery.

Debulking is a key aspect for meningioma resection, which is accomplished through the use of microsuction in conjunction with an ultrasonic aspirator. The bimanual technique enables the surgeon to fully expose and identify the arachnoid plane around the tumour. It is critical to fully develop the arachnoid plane with a no-touch technique on the brain side before the tumour is completely released and removed. The patient made an uncomplicated recovery and was discharged to home with no neurological deficits.

Contributors We certify that we have each made a substantial contribution as to qualify for authorship as follows: OC, NDA and PP performed the procedure, OC provided video narration, GG and PP performed critical video editing and preparation for publication.

Funding The authors have not declared a specific grant for this research from any funding agency in the public, commercial or not-for-profit sectors.

Competing interests None declared.

Patient consent for publication Obtained.

Provenance and peer review Not commissioned; externally peer reviewed. 
Images in...

Copyright 2019 BMJ Publishing Group. All rights reserved. For permission to reuse any of this content visit https://www.bmj.com/company/products-services/rights-and-licensing/permissions/

BMJ Case Report Fellows may re-use this article for personal use and teaching without any further permission.

Become a Fellow of BMJ Case Reports today and you can:

- Submit as many cases as you like

Enjoy fast sympathetic peer review and rapid publication of accepted articles

Access all the published articles

Re-use any of the published material for personal use and teaching without further permission

Customer Service

If you have any further queries about your subscription, please contact our customer services team on +44 (0) 2071111105 or via email at support@bmj.com.

Visit casereports.bmj.com for more articles like this and to become a Fellow 